\title{
Listed Companies' Income Tax Planning and Earnings Management: Based on China's Capital Market
}

\author{
Nanwei Hu${ }^{1}$, Qiang $\mathrm{CaO}^{2 *}$, Lulu Zheng ${ }^{1}$ \\ ${ }^{1}$ China University of Mining \& Technology (Beijing), (China) \\ ${ }^{2}$ Central University of Finance and Economics (China) \\ ananmusii@foxmail.com,*Corresponding author: caoqiang915093@aliyun.com,352375919@qq.com
}

Received: November 2014

Accepted: February 2015

\section{Abstract:}

Purpose: The Ministry of Finance issued the new China accounting standards on February 15, 2006(CAS2006), which requires the listed companies to use the balance sheet liability method for the income tax accounting. Thus, it gives us an opportunity to investigate the earnings management of listed companies from the perspective of income tax. Under the balance sheet liability method, our researches just try to investigate the relationship between the listed companies' income tax planning and earnings management.

Design/methodology/approach: Our research approach combines theoretical analysis and empirical analysis. This paper first makes a deep theoretical analysis on the listed companies' choice between pretax earnings management activities and earnings management activities, and then we exemplify our theory. Next, we come up with two hypotheses based on the theoretical analysis, build up a restatement model and conduct the empirical examination. The empirical analysis employs the method of descriptive statistics and logistic regression.

Findings: When engaging in earnings management, listed companies will trade off conforming and nonconforming earnings management from the perspective of income tax cost. We find that managers' motivations and purposes will influence the choice. When the company has motivations to turn losses into gains and has motivations to avoid penalty cost 
associated with fraud being found, the company prefers to employ more conforming earnings management strategies.

Research limitations/implications: The limitation in our research is as follows. First, we mainly focus on the conforming and nonconforming earnings management when the listed companies restate their financial statements. However after the issue of CAS2006, many listed companies still not disclose income tax account, which restrict our sample. Second, without the acquisition of private companies' data, our empirical results may have some errors. We will solve these problems in our future study.

Practical/social implications: First of all, our research provides new perspective and theoretical evidence for exploring the listed companies' choice of conforming and nonconforming earnings management. Meanwhile, our results are helpful for regulators to strengthen the administration of listed companies' restatement. Finally, our results will help us to deeply understand the impact of the accounting processes of income tax under the balance sheet liability method on the listed companies.

Originality/value: So far, there are few studies discussing the choice of earnings management strategies and how different purposes and motivations affect the choice from the perspective of income tax. The issue of CAS2006 offers an opportunity for this research. This paper use restatement as sample to investigate the choice of conforming earnings management and nonconforming earnings management under different motivations and purposes for the first time.

Keywords: earnings management, book-tax differences, deferred tax expense

\section{Introduction}

With the stakeholders pay more attention to earnings information, earnings management prevail among the listed companies. But there is no doubt that it decreases the quality of listed companies' financial information and whitewashed earnings information can't fairly reflect firms' financial status and operating results, which hurts the interests of information users. So it is especially important to study on earnings management, and the implement of the CAS2006 highlights the importance of our study at the same time.

The Ministry of Finance issued the CAS2006 on February 15, 2006, which consists of the basic criteria, 38 specific criteria and application guide for criteria. CAS2006 require the listed companies to use balance sheet liability approach to conduct tax income accounting, and firstly 
introduce the concept of assets, liabilities tax basis and confirm deferred tax assets, deferred liabilities on the basis of 'Asset-Liability View'. There are some huge differences in the concepts and methods of tax accounting between the balance sheet liability approach and the taxes payable methods or tax effect accounting, thus the new standards provide new space for the options of earnings management strategies. National People's Congress passes the "PRC Enterprise Income Tax Law" on March 16, 2007 and the law is implemented from January 1, 2008. Tax will not only affects companies' profits, but also be closely related to firms' earnings management activities. Different earnings management strategies have different tax cost and the amount of income tax that needs to pay in current period will also vary. Besides, the amount of income tax that needs to pay is closely related to firms' free cash flow. On one hand, the amount of income tax that needs to pay in current period is firms' cash outflow which decrease the net amount of cash flow generated from the business activities and thus decrease the free cash flow. On the other hand, the level of free cash flow restricts the amount of income tax that needs to pay and thus influences firms' choice of earnings management strategies, for example, when a firm has the high level of free cash flow, which means the cash that can be available to pay for income tax is sufficient, the firm won't care the amount of income tax that need to pay in current period. So because income tax cost is associated with earnings management, firms need to choose conforming earnings management and/or nonconforming earnings management. It is clear that the promulgation of CAS2006 and the implementation of the tax law provide the background for our study.

Presently, the researches of earnings management in academia mostly focus on the cost, motivations, means and results of earnings management. There are few studies discuss the choice of earnings management strategies and the different purposes and motivations that affect the choice from the perspective of income taxes. We try to explore the choice of different earnings management strategies and the motivations that affect the choice from the perspective of the income tax. We not only investigate the effect of earnings management on income tax, but also the effect of different earnings management motivations on the choice of earnings management strategies.

In addition, our sample offers the potential for this study. Consistent with Erickson, Hanlon and Maydew (2004), income-increasing conforming earnings management results in a downward restatement of current tax expense as well as pretax income. Consistent with Phillips, Pincus and Rego (2003), income-increasing nonconforming earnings management results in a downward restatement of deferred tax expense and pretax income. Restatement companies that managed pretax earnings upward in ways that create permanent book-tax differences would restate pretax income downward, but not restate either current or deferred tax expense. By definition, companies that manage earnings in such a manner do not incur any current or deferred income tax costs related to the earnings management. We measure this type of pretax earnings management by our misstatement companies and find little evidence of such activity, consistent with companies having limited opportunities to engage in this type of 
earnings management. Accordingly, we focus on nonconforming earnings management that creates temporary book-tax differences and thus greater deferred tax expense. Hence, restatements of income tax accounts reveal the type of pretax earnings management (i.e., book-tax conforming or nonconforming) that managers employ. Based on this, we choose misstatement firms as our sample, which enable us to investigate the choice of conforming and nonconforming earnings management through measuring the differences of tax account between originally reported and restated financial statements, and to measure the amount of pretax earnings management more accurately. Restating financial results can presumably still reflect unacknowledged earnings management, nonetheless, we assume that restated amounts reflect strictly less earnings management than the amounts companies originally reported.

\section{Prior Research}

Our study builds upon several streams of researches, including studies that investigate earnings management accomplished via book-tax conforming and nonconforming strategies.

Scholes, Wilson and Woflson (1990), Matsunaga, Shevlin and Shores (1992), and Dhaliwal, Frankel and Trezevant (1994) focus on book-tax conforming upward earnings management, which increases both financial and taxable incomes and thus has current tax consequences. That is, conforming earnings management includes any transaction that has the same impact on the current financial and taxable incomes. A common example of conforming earnings management is accelerating revenue recognition by recording receivables sooner than justifying and postponing inventory purchases under LIFO.

In contrast, Mills and Newberry (2001), Joos, Pratt and Young (2003), Phillips, Pincus and Rego (2003) and Phillips, Pincus, Rego and Wan (2004) focus on nonconforming upward earnings management, which increases financial accounting income with no current tax consequences. This type of earnings management includes transactions that accelerate revenue recognition or defer expense recognition for financial reporting purposes relative to tax purposes, such as aggressively recognizing unearned revenue, extending the useful lives of depreciable assets, or reducing the provision for doubtful accounts for financial reporting purposes.

Frank, Lynch and Rego (2009) find that previous studies conclude that firms will make a tradeoff between increase financial incomes and decrease taxable incomes. In fact, this understanding is based on the consistence between accounting and tax rules, that is, firms need to pay high tax cost for increasing financial incomes. But with the book-tax differences, which tends to expand, and managers' discretion given by CAS2006, firms are able to increase financial incomes without increasing taxable incomes, that is, pay little or no tax cost for increasing financial incomes. 
Ye (2006) investigates the trade-off between the cost of financial report and income tax based on A-shares manufacturing firms' data. The empirical results show that the more earnings listed companies' managers manage, the higher the book-tax differences are, which means the listed companies accomplish earnings management via nonconforming earnings management to avoid income tax cost, but results also show that the avoidance is limited.

Liang (2010) concludes that no matter what the goal of earnings management is, listed companies prefer to earnings management strategies accompanying "zero tax cost".

Long and Chen (2010) use book-tax difference to measure earnings management. Based on the listed companies' data in stock markets of Shanghai and Shenzhen from 2000 to 2006, they find that the book-tax differences are significantly different in firms with different ownership structure and private listed companies with system whereby state-owned enterprises pay tax plus a percentage of profits will pay more attention to trade-off cost of financial report and income tax and thus tend to choose nonconforming strategies when engaging in earnings management activities.

$\mathrm{Hu}$ (2010) confirms that in order to make the right decisions, firms have the motivation to avoid income tax cost through nonconforming earning management and the higher the degree of earnings management and the tax rate is, the higher earnings firms manage through nonconforming earnings management. The study also finds that income tax cost evaded by this approach is extremely limited and it perhaps reveals that firms in fact pay income tax cost for most earnings management.

The above studies examine the relationship between earnings and income tax and the balance of financial reporting and income tax costs, but few domestic researches reflect earnings management behavior by financial restatements, also few are based on the differences of income tax account between originally reported and restated financial statements to investigate firms' choice among different earnings management strategies and how manager's motivations and purposes influence this choice. Relative to previous studies, we estimate the choice of conforming earnings management and nonconforming earning management from the perspective of income tax and we use the changes in current and deferred tax expense disclosed in earnings' restatements to measure conforming and nonconforming earnings management.

\section{Theoretical Analysis}

Based on the treatment of book-tax differences using the balance sheet liability method, this article analyzes the effect that different earnings management strategies have on book-tax differences and the level of income tax burden under different earnings management 
strategies. We conclude that when manage earnings, managers tend to choose nonconforming earnings management strategies from the perspective of income tax.

\subsection{Treatment of Book-Tax Differences}

Figure 1 schematically illustrates the accounting processes of Corporate Income Tax under the balance sheet liability method. The balance sheet liability method means starting from the balance sheet, recognizing taxable temporary differences and deductible temporary differences by comparing difference between the book value that is determined in accordance with GAAP and tax basis that is determined according to the provisions of the Income Tax Law and then recognizing deferred income tax liabilities and deferred income tax assets and thus determining the income tax expense for each period. Shown in Figure 1, when companies engage in earnings management, managers can choose conforming earnings management strategies, strategies affect both accounting profit and taxable income and thus have effect on current income tax expense without having effect on deferred income tax expense, and they can also choose nonconforming earnings management strategies, strategies only affect accounting profit and don't affect taxable income and thus have effect on deferred income tax expense without having effect on current income tax expense. Of course, companies can adopt both two kinds of earnings management strategies. The two earnings management strategies have different influence on current income tax expense. Thus, the company can decrease the current period's tax payable through choosing different earnings management. 


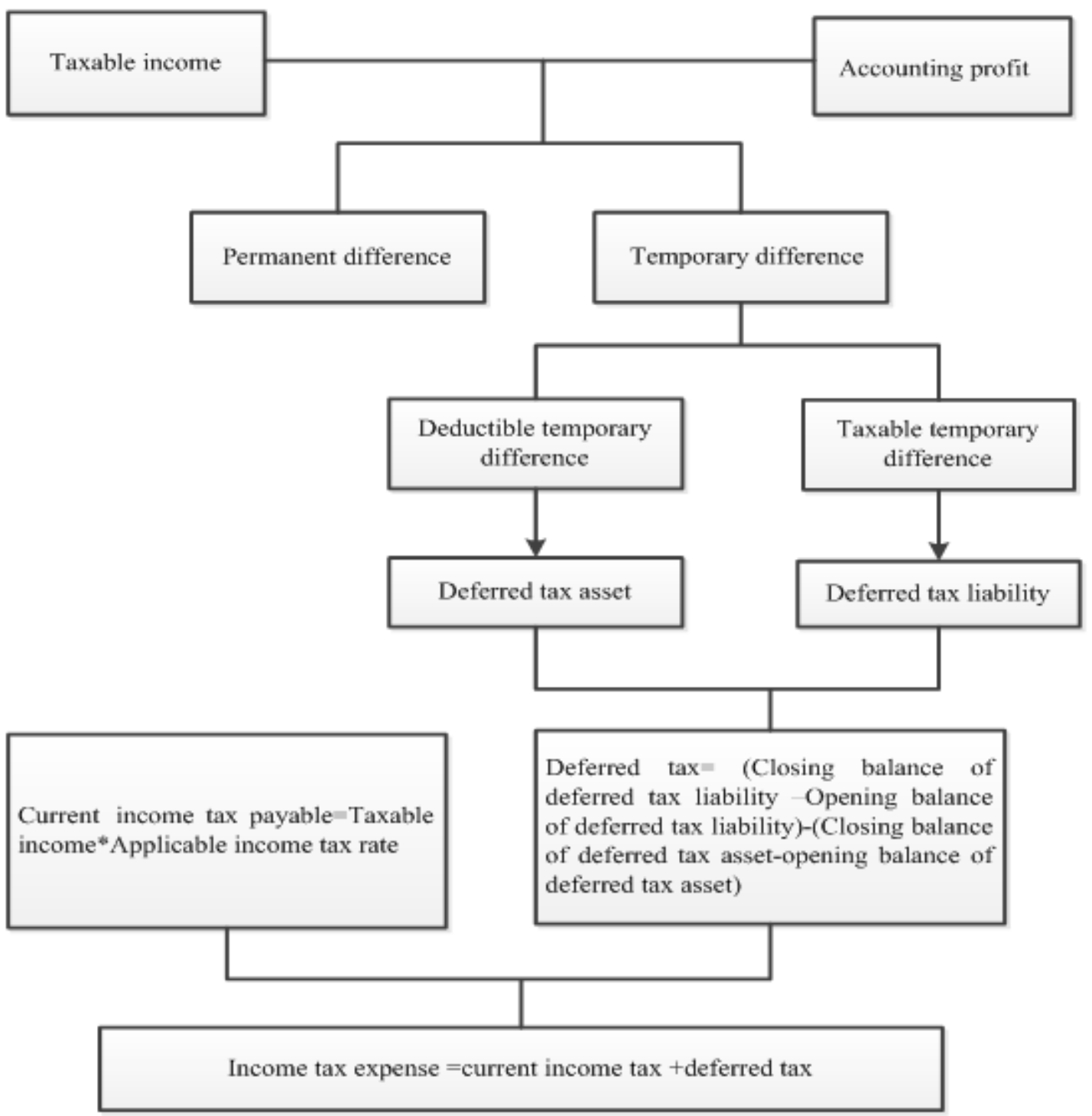

Figure 1. The accounting processes of corporate income tax

\subsection{Earnings Management Strategies and Book-Tax Differences}

With the steady progress in the reform process of CAS, companies get more opportunities to choose accounting policies and accounting estimates, these factors led to the differences between Chinese listed companies' accounting profits and taxable income. And this also result in the increase of managers' choice of earnings management strategies. This paper mainly discusses the relationship between the choice of different earnings management strategies, conforming earnings management strategies and nonconforming earnings management strategies, and book-tax differences. We focus on earnings management bringing temporary differences, because companies rarely have the opportunity to engage in earnings management generating permanent differences. When companies engaged in conforming earnings management strategies, the book-tax differences will be generated, while when companies engaged in nonconforming earnings management strategies, the book-tax differences will not be generated. And the more nonconforming earnings management 
strategies companies engaged in, the greater the book-tax differences are. We illustrate the relationship between the two different earnings management strategies and book-tax temporary differences through the following example.

Assume that in the current year $t$ and also in year $t+n$, both company $A$ and company $\mathrm{B}$ have $¥ 1000$ of "true" pretax book income. The company $A$ engages in $¥ 100$ of earnings management through a conforming manner and thus originally reports $¥ 1100$ of pretax income in year $t$. While the company $B$ engages in $¥ 100$ of earnings management through $a$ nonconforming manner and thus also originally reports $¥ 1100$ of pretax income in year $t$. As a result, the changes in the two companies' book-tax differences and income tax expenses before and after engaging in earnings management is as follows (the income tax rate is 25 percent):

\begin{tabular}{|l|r|r|}
\cline { 2 - 3 } \multicolumn{1}{c|}{} & Company A & \multicolumn{2}{c|}{ Company B } \\
\hline Accounting profit & 1,100 & 1,100 \\
\hline Taxable income & 1,100 & 1,000 \\
\hline Current income tax payable & 275 & 250 \\
\hline Book-tax differences & 0 & 100 \\
\hline Deferred tax expenses & 0 & 25 \\
\hline
\end{tabular}

Table 1. After engaging in earnings management. (Unit: million)

\begin{tabular}{|l|r|r|}
\cline { 2 - 3 } \multicolumn{1}{c|}{} & Company A & \multicolumn{2}{c|}{ Company B } \\
\hline Accounting profit & 1,000 & 1,000 \\
\hline Taxable income & 1,000 & 1,000 \\
\hline Current income tax payable & 250 & 250 \\
\hline Book-tax differences & 0 & 0 \\
\hline Deferred tax expenses & 0 & 0 \\
\hline
\end{tabular}

Table 2. Before engaging in earnings management. (Unit: million)

As shown in Table 1 and Table 2, conforming earnings management will not cause book-tax differences, but it will affect taxable income and thus this earnings management strategy only affects current income tax payable and has no effect on deferred income tax expense. In the contrary, nonconforming earnings management will cause book-tax differences, but it will not affect taxable income and thus this earnings management strategy only affects deferred income tax expense and having no effect on current income tax payable. 


\subsection{Earnings Management and Income Tax Burden}

In the capital market, the management of listed companies often engaged in earnings management consciously for the purpose of financing, contract or political control (Healy \& Wahlen, 1999). However, earnings management is not without cost, in addition to potential legal costs, one of the direct costs of earnings management is the income tax cost: when the management attempt to increase profits through earnings management, they often need to pay more income tax for the increasing profit. Therefore, in most cases, when companies increase profits through earnings management, the income tax burden will be affected. Exclude minority earnings management producing permanent differences, compared to conforming earnings management, nonconforming earnings management can bring income tax benefit. Follow the above example:

Assuming both company $\mathrm{A}$ and company $\mathrm{B}$ reverse the temporary differences in the year $t+n$. Since company A performs earnings management in a conforming manner, company A would incur income tax costs of $¥ 275$ in year $t$ ( $¥ 1100 \times 25$ percent) and $¥ 225$ in year $t+n$ ( $¥ 900 \times 25$ percent). The present value of income tax costs would be $¥ 275+\left[¥ 225 /(1+r)^{n}\right]$, where $r$ is company's discount rate. Company B performs earnings management in a nonconforming manner, company B would incur income tax costs of $¥ 250$ in year $t(¥ 1000 \times 25$ percent) and $¥ 250$ in year $t+n$ ( $¥ 1000 \times 25$ percent) since nonconforming earnings management does not affect taxable income (in this case, $¥ 1000$ ). The present value of income tax costs would be $¥ 250+\left[¥ 250 /(1+r)^{n}\right]$, where $r$ is the company’s discount rate.

The income tax benefit from engaging in nonconforming versus conforming upward earnings management equals the net present value of income tax benefits from doing so, i.e., the present value of income tax costs associated with conforming earning management minus the present value of income tax costs associated with nonconforming earnings management. This amount is computed as:

$$
\left\{¥ 275+\left[¥ 225 /(1+r)^{n}\right]\right\}-\left\{¥ 250+\left[¥ 250 /(1+r)^{n}\right]\right\}=¥ 25-\left[¥ 25 /(1+r)^{n}\right] .
$$

It can be seen that, the present value of income tax costs associated with nonconforming earning management is lower than that of income tax costs associated with conforming earning management, that is, compared to company $A$, company $B$ can bring income tax benefits. Thus, companies can achieve the purpose of reducing the income tax burden through the choice of conforming earning management and nonconforming earning management. 


\section{Research Design}

\subsection{Hypothesis}

Book-tax conforming upward earnings management increases both financial and taxable incomes and thus has current tax consequences; nonconforming upward earnings management increases financial accounting income but has no current tax consequences. Compared to conforming upward earnings management, nonconforming earnings management can decrease current income tax expense and thus increase firms' cash flow, so firms prefer to manage earnings upward in a nonconforming manner to avoid income tax cost. We suppose managers' motivations and purposes influence the choice. When firms are facing punishment of the suspension or termination of the listing for three consecutive losses, firms will have a great incentive to manage earnings in order to turn losses into gains. Thus, when firms have motivations to turn losses into gains, firms can't wait to manage earnings to increase incomes and won't consider income tax cost too much. And if they employ nonconforming earnings management which bring greater book-tax differences, it may increase the probability of being detected and earnings management behavior may also be found. Thus, we predict that in this motivation, listed companies will employ more conforming earnings management. Therefore, the hypothesis 1 is:

H1: When the firm has motivations to turn losses into gains, the firm prefers to employ more conforming earnings management strategies.

It can be seen that, conforming earnings management don't generate book-tax difference, while nonconforming earning management generate book-tax difference and the greater the earnings management degree is, the greater the difference is. The book-tax difference tends to attract regulatory agencies' attention, as Frank, Lynch and Rego (2006) think it will attract attention of SEC, so the detection cost associated with nonconforming earnings management is greater than that with conforming. We think that the greater the detection cost associated with nonconforming earnings management is, the less the earnings firms manage in a nonconforming manner. And we use fraud as proxy for detection cost, thus, when the firms engage in fraudulent activities (the detection cost is greater), they prefer to employ more conforming earnings management strategies. On the other hand, if firms engaging in fraudulent activities employ nonconforming earnings management bringing greater book-tax difference which is easy to attract regulatory agencies' attention, the fraud may be found. Therefore, the firms engaging in fraudulent activities will employ more conforming earnings management strategies to avoid penalty cost associated with fraud being found. Therefore, the hypothesis 2 is:

H2: When the firm has the motivation to avoid penalty cost associated with fraud being found, the firm prefers to employ more conforming earnings management strategies. 


\subsection{Sample}

Chinese listed companies began to implement CAS2006 in 2007 and companies generally restate financial statements in the year following the misstatement period. Thus, we think that only restatements in 2008 and after 2008 can offer the data we need. Base on this, we identify misstatement firms (i.e., firms that restated their financial statements in a subsequent year) as the A-share listed company's report in Shanghai and Shenzhen Stock Exchange from 2008 to 2010, the data comes from CSMAR.

We first get 435 misstatement firms as sample. The restatements corrected previous material misstatements of financial statement numbers caused by accounting irregularities. We manually collect the following variables from both the originally reported and restated financial statements: total assets, pretax net income and restated income, current tax expense, deferred tax expense from operations. Then we lose 202 firms without above variables data. We finally get our misstatement sample consisting of 223 misstatement firms.

\subsection{Model and Variable Definitions}

\subsubsection{Model}

To explore managers' different motivations and purposes that impact the choice of conforming and nonconforming earnings management $(\mathrm{H} 1$ and $\mathrm{H} 2)$, we estimate the following regression model:

$$
\begin{aligned}
\text { NONCON_EM }=a_{0}+ & a_{1} T L T G_{i}+a_{2} F R A U D_{i}+a_{3} L A G \_D T E_{i}+a_{4} L N L A G_{-} T A_{i}+ \\
& a_{5} R E V \_O N L Y_{i}+a_{6} E X P_{-} O N L Y_{i}+\varepsilon_{i}
\end{aligned}
$$

Where:

NONCON_EM equals 1 if the firm employs nonconforming earnings management, and 0 otherwise;

TLTG equals 1 if the firm turns losses into gains in year $t$, and 0 otherwise;

FRAUD equals 1 if the firm engages in fraudulent activities in year $\mathrm{t}$, and 0 otherwise;

LAG_DTE equals deferred tax expense in year $\mathrm{t}-1$, scaled by total assets at year-end $\mathrm{t}-2$;

LAG_TA equals the logarithm of total assets at year-end $\mathrm{t}-1$;

REV_ONLY equals 1 if the firm only restates revenue accounts in year $t$, and 0 otherwise; 
EXP_ONLY equals 1 if the firm only restates expense accounts in year $t$, and 0 otherwise;

Year $\mathrm{t}$ is the year in which firm restates its financial statements. When firm restates multiple years' financial statements, year $t$ is the first misstatement year.

\subsubsection{Variable Definitions}

NONCON_EM, which is the dependent variable in Model (1), is used to measure the restatement firm employs nonconforming earnings management. Specially, if the firm only restates deferred income tax expense, we can judge that it employs nonconforming earnings management; if the firm only restates current income tax expense, we can judge that it employs conforming earnings management; if the firm not only restates deferred income tax expense, but also restates current income tax expense, we need to compare the relative amount of the differences of current and deferred tax expense account between originally reported and restated financial statements to judge which type of earnings management it is engaged in and when the amount of difference in deferred tax expense is greater than that in current tax expense, we think the firm employs nonconforming earnings management.

TLTG, which is the independent variable in Model (1), is used to measure whether the restatement firm has the motivation to turn losses into gains in the year that the misstatement occurs. If the firm's pretax net income that disclosed in originally financial statement is positive but negative in restated financial statement, we can judge that the firm has the motivation to turn losses into gains.

FRAUD, which is the independent variable in Model (1), is used to measure whether the firm has the motivation to avoid penalty cost associated with fraud being found. If there are words "fraud", "fiction", "published by SFC or the tax authorities" or "special inspected or questioned by independent third party, such as SASAC, the Ministry of Finance, the Audit Committee, the independent directors" in all restatement firms' misstatement information, we think that the firm engages in fraud.

Consistent with $\mathrm{H} 1$ and $\mathrm{H} 2$, we believe the coefficients of $\mathrm{a}_{1}$ and $\mathrm{a}_{2}$ in Model (1) are negative, that is, the listed firms engage in more conforming earnings management.

Because there are likely different costs and benefits associated with different types of earnings management, we include two additional indicator variables in model (1), one for misstatements only involving revenue recognition ( $R E V \_O N L Y$ ) and the other for misstatement only involving expense recognition (EXP_ONLY). If there is a systematic relation between revenue and expense management, whether such earnings management is achieved via a conforming or nonconforming manner, our results could be biased. Thus, we introduce 
variables REV_ONLY and EXP_ONLY to control a possible link between earnings management type (conforming or nonconforming) and the type of account managed (revenue-only and expense-only) in our multivariate analysis.

Finally, we include $L N L A G_{-} T A$, the Logarithm of total assets at year-end $\mathrm{t}-1$, to control firm size. Because compared to relative little firms, large firms' operating, financing, and investing activities are more complex, they have more opportunity to manage earnings. In addition, because large deferred tax expense in the year prior to the misstatement period limits the firm' ability to engage in more nonconforming earning management in the misstatement year, we also include $L A G \_D T E$, deferred tax expense in the year prior to the misstatement period, to control for the prior year's nonconforming earnings management.

\section{The Empirical Results}

\subsection{Descriptive Statistics}

Table 3 shows the descriptive statistics of NONCON_EM by TLTG, FRAUD classification. The descriptive statistics show that, on the one hand, the mean of NONCON_EM is less than 0.5 when the firm engages in fraudulent activities and turns losses into gains. Even in the presence of permanent differences (as already said the case is relatively less), we can also consider the mean of NONCON_EM is less than the mean of CON_EM. More importantly, on the other hand, when the FRAUD and TLTG varies from 0 to 1 , the means of NONCON_EM are smaller. These all show that when the firm engages in fraudulent activities and turns losses into gains, the firm prefers to employ less nonconforming earnings management strategies. The two aspects indicate that when the firm has motivations to turn losses into gains and has the motivation to avoid penalty cost associated with fraud being found, the firm prefers to employ more conforming earnings management strategies.

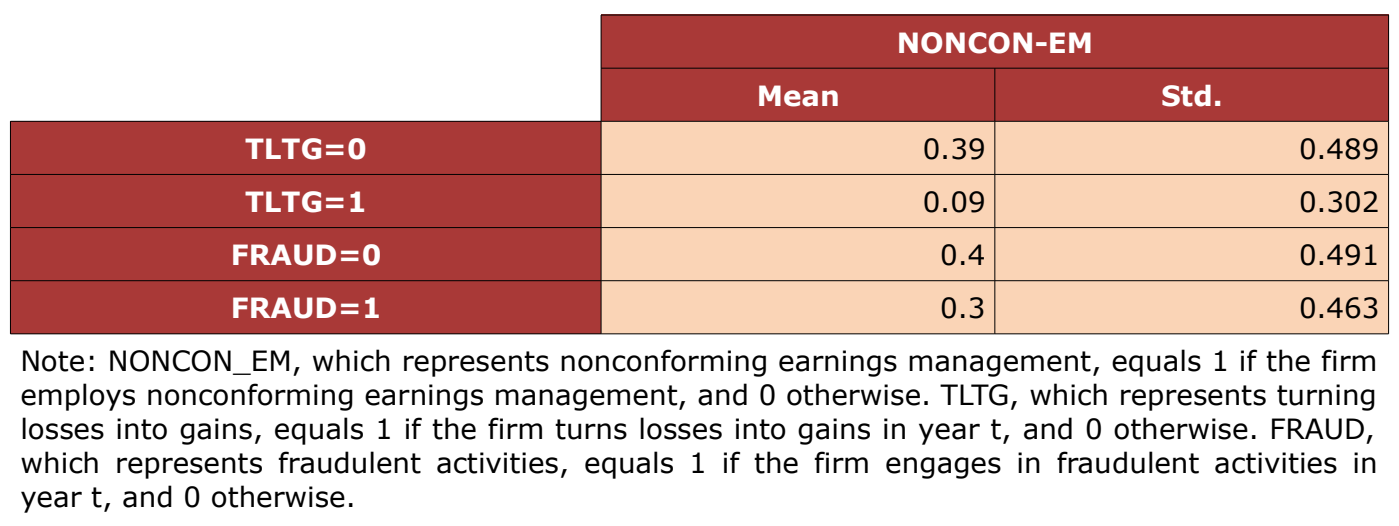

Table 3. Descriptive statistics of NONCON-EM 
Table 4 presents Pearson correlation test of the variables in the Model (1). The results show that two test variables, TLTG and FRUAD, are negatively related to the dependent variable (NONCON_EM), which is consistent with the hypothesis. It is noteworthy that the correlation coefficient between each variable is small, which explains that the Model (1) doesn't exist large linear problems.

\begin{tabular}{|c|c|c|c|c|c|c|c|}
\hline & NONCON_EM & TLTG & FRAUD & REV_ONLY & LNLAG_TA & EXP_ONLY & LAG_DTE \\
\hline NONCON_EM & 1 & & & & & & \\
\hline TLTG & -0.132 & 1 & & & & & \\
\hline FRUAD & -0.084 & -0.116 & 1 & & & & \\
\hline REV_ONLY & 0.153 & -0.041 & 0.304 & 1 & & & \\
\hline LNLAG_TA & 0.158 & -0.129 & 0.091 & 0.123 & 1 & & \\
\hline EXP_ONLY & -0.154 & 0.035 & 0.038 & -0.525 & -0.116 & 1 & \\
\hline LAG_DTE & 0.058 & -0.020 & 0.174 & 0.073 & -0.038 & 0.035 & 1 \\
\hline
\end{tabular}

Table 4. Correlation test

\subsection{Multivariate Testing}

Table 5 reflects the main regression results of the Model (1) and the results reflect the test of both $\mathrm{H} 1$ and $\mathrm{H} 2$. As can be seen, the coefficients of TLTG and FRAUD are significantly negative which are consistent with our expectations. As predicted by $\mathrm{H} 1$, when the firm has motivations to turn losses into gains, the firm prefers to employ more conforming earnings management strategies. As predicted by $\mathrm{H} 2$, when the firm has the motivation to avoid penalty cost associating with fraud being found, the firm prefers to employ more conforming earnings management strategies, which is consistent with the results in Erickson et al. (2004), who document that their sample of firms with fraudulent financial reporting relied on significant amounts of conforming earnings management. In sum, these results show that when the firm has motivations to turn losses into gains, the firm prefers to employ more conforming earnings management strategies; when the firm engages in fraudulent activities, the firm prefers to employ less nonconforming earnings management strategies.

In summary, we confirm $\mathrm{H} 1$ and $\mathrm{H} 2$ by descriptive statistics and multivariate tests. Different motivations do influence the choice of earnings management strategies, specifically, when the firm has motivations to turn losses into gains and has the motivation to avoid penalty cost associating with fraud being found, the firm prefers to employ more conforming earnings management strategies. 


\begin{tabular}{|l|r|r|r|r|}
\cline { 2 - 5 } & Symbol & Coefficient & Sig. & \multicolumn{2}{c|}{ Z value } \\
\hline (Constant) & $?$ & -1.96 & 0.053 & 3.732 \\
\hline TLTG & - & $-1.903^{*}$ & 0.078 & 3.096 \\
\hline FRAUD & - & $-0.900 * *$ & 0.022 & 5.248 \\
\hline REV_ONLY & $?$ & $0.685^{*}$ & 0.067 & 3.361 \\
\hline EXP_ONLY & $?$ & -0.262 & 0.577 & 0.311 \\
\hline LAG_DTE & - & 8.372 & 0.308 & 1.041 \\
\hline LNLAG_TA & $?$ & $0.190 * *$ & 0.050 & 3.834 \\
\hline
\end{tabular}

Note: $*, * *, * * *$ indicate the coefficient is significant at the level of $10 \%, 5 \%, 1 \%$.

TLTG, which represents turning losses into gains, equals 1 if the firm turns losses into gains in year $\mathrm{t}$, and 0 otherwise. FRAUD, which represents fraudulent activities, equals 1 if the firm engages in fraudulent activities in year $\mathrm{t}$, and 0 otherwise. $R E V \_O N L Y$, control variable, equals 1 if the firm only restates revenue accounts in year $t$, and 0 otherwise. EXP_ONLY, control variable, equals 1 if the firm only restates expense accounts in year $t$, and 0 otherwise. LAG_DTE equals deferred tax expense in year $\mathrm{t}-1$, scaled by total assets at year-end $\mathrm{t}-2$. LAG_TA equals logarithm of total assets at year-end $\mathrm{t}-1$.

Table 5. Logistic regression of Model (1)

\section{Conclusions and Recommendations}

Based on CAS2006, we examine listed companies' choice of two types of earnings management: book-tax conforming and book-tax nonconforming. And we also examine how firm-specific motivations and purposes impact the choice among these earnings management strategies. We base our analyses on a sample of firms that restated their earnings (and thus had managed earnings), and we measure conforming and nonconforming earnings management by using the changes in current and deferred tax expense account disclosed in originally and restated financial statements. We compare the relative amounts of changes in current and deferred tax expense to judge which type of earnings management a firm is engaged in.

Using hand-collected data from the misstatement firms' financial statements, we get values of the variables in Model (1). Then we get the conclusions by analyzing results of descriptive statistics and correlation test and logistic regression of Model (1).

The study indicates that when the firm has motivations to turn losses into gains and has the motivation to avoid penalty cost associating with fraud being found, the firm prefers to employ more conforming earnings management strategies. Based on the study, we present several policy recommendations to regulate earnings management.

\subsection{Improve Accounting Standards}

The relevant authorities should learn from the relevant provisions of international accounting standards to improve and revise our existing accounting standards and its core ideas should be 
to narrow space that firms are free to choose. Specifically, the language and concept of accounting standards should be standardized; reduce the alternative accounting policies and methods; minimize management's accounting estimates and professional judgment; standardize changing conditions of accounting policies and accounting estimates and corrections of accounting error.

\subsection{Optimization Pay System}

Currently, managers' revenues consist of basic salary and bonus in most enterprises and the basic salary and bonus are linked to managers' performance. It can be seen that managers' compensation mechanisms not only incentive managers to focus on financial performance of corporate, but also induce earnings management activities. Therefore, to optimize the compensation mechanisms is an effective method to prevent earnings management activities. On the one hand, combine long-term development of the firm to managers' revenues; on the other hand, give managers the appropriate option awards to align the interests of managers and shareholders together, so that to promote managers to pay more attention to the firm's long-term development and thus weaken their incentives to manage earnings.

\section{Current Projects}

This paper has been supported by grants from the National Natural Science Foundation of China (No.71302123) (No.71102126), Science Foundation of Ministry of Education of China (No. 13YJC790048) and the Specialized Research Fund for the Doctoral Program of Higher Education of China (Grant No. 20120023120015) and the Innovative Research Team of Central University of Finance and Economics.

\section{References}

Dhaliwal, D., Frankel, M., \& Trezevant, R. (1994). The taxable and book income motivations for a LIFO layer liquidation. Journal of Accounting Research, 2, 278-289.

http://dx.doi.org/10.2307/2491286

Erickson, M., Hanlon, M., \& Maydew, E. (2004). How much will firms pay for earnings that do not exist? Evidence of taxes paid on allegedly fraudulent earnings. The Accounting Review, 79(2), 387-408. http://dx.doi.org/10.2308/accr.2004.79.2.387 
Frank, M., Lynch, L., \& Rego, S. (2006). Does aggressive financial reporting accompany aggressive tax reporting (and Vice Versa)?. Working paper, University of Virginia and Iowa.

Frank, M., Lynch, L., \& Rego, S. (2009). Tax reporting aggressiveness and its relation to aggressive financial reporting. The Accounting Review, 2, 467-496.

http://dx.doi.org/10.2308/accr.2009.84.2.467

Healy, P.M., \& Wahlen, J.M. (1999). A review of earnings management literatures and its implications for standard setting, Accounting Horizon, 13(4), 365-383.

http://dx.doi.org/10.2308/acch.1999.13.4.365

$\mathrm{Hu}$, T. (2010). The empirical research of earnings management and the corporate income tax burden. Friends of Accounting, 11, 90-93.

Joos, P., Pratt, J., \& Young, S.D. (2003). Using deferred taxes to infer the quality of accruals. Working paper, Massachusetts Institute of Technology.

Liang, X.C. (2010). The empirical research of earnings management behavior's preference: Based on income tax cost. Working paper, Shandong Institute of Business and Technology.

Long, L.H., \& Chen, J.J. (2010). Ownership Property, tax cost and earnings management: Research based on book-tax difference. Working paper, Shanghai Lixin University of Commerce.

Matsunaga, S., Shevlin, T., \& Shores, D. (1992). Disqualifying dispositions of incentive stock options: Tax benefits versus financial reporting costs. Journal of Accounting Research, 30(Supplement), 37-68. http://dx.doi.org/10.2307/2491192

Mills, L., \& Newberry, L.K. (2001). The influence of tax and nontax costs on book-tax reporting differences: Public and private firms. Journal of the American Taxation Association, 23(1), 1-19. http://dx.doi.org/10.2308/jata.2001.23.1.1

Phillips, J., Pincus, M., \& Rego, S. (2003). Earnings management: New evidence based on deferred tax expense. The Accounting Review, 78(2), 491-521.

http://dx.doi.org/10.2308/accr.2003.78.2.491

Phillips, J., Pincus, M., Rego, S., \& Wan, H. (2004). Decomposing changes in deferred tax assets and liabilities to isolate earnings management activities. The American Taxation Association, 26(Supplement) 43-66. http://dx.doi.org/10.2308/jata.2004.26.s-1.43 
Scholes, M., Wilson, P., \& Woflson, M. (1990). Tax planning, regulatory capital planning, and financial reporting strategy for commercial banks. The Review of Financial Studies, 3(4), 625-650. http://dx.doi.org/10.1093/rfs/3.4.625

The Ministry of Finance. (2006). Accounting Standards for Business Enterprises: Economic Science Press.

Ye, K.T. (2006). Earnings management and payment of income tax: research based on booktax difference. China Accounting Review, 2, 205-223.

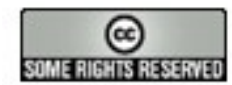

Article's contents are provided on a Attribution-Non Commercial 3.0 Creative commons license. Readers are allowed to copy, distribute and communicate article's contents, provided the author's and Journal of Industrial Engineering and Management's names are included. It must not be used for commercial purposes. To see the complete license contents, please visit http://creativecommons.org/licenses/by-nc/3.0/. 